\title{
Humane Harvesting Initiative: The Influence of Humane Harvesting on Fish Quality, Nutritional Value and Safety
}

\author{
Mahmoudreza Ovissipour ${ }^{1 *}$, Kenny Down², Gleyn E Bledsoe ${ }^{3}$ and \\ Barbara Rasco ${ }^{4}$ \\ 1Department of Biological Systems Engineering, Washington State University, USA \\ 2Blue North Inc., USA \\ 3University of Idaho, USA \\ ${ }^{4}$ School of Food Science, Washington State University, USA
}

\section{Review Article \\ Volume 1 Issue 1}

Received Date: June 06, 2016

Published Date: June 24, 2016

*Corresponding author: Mahmoudreza Ovissipour, Department of Biological Systems Engineering, Washington State University, Pullman, WA, 99164, USA, Email: m.ovissipour@wsu.edu

\section{Abstract}

Recently, fish welfare particularly during pre-slaughtering and slaughtering procedures is become prominent in fishery and seafood industry. The response to stress starts in the brain and is followed by biochemical changes in the blood and subsequent behavioral changes. There are differences between fish welfare in aquaculture and fisheries. In aquaculture, the welfare could be controlled by managing the crowding, feeding, handling, disease, transportation, drug administration, water quality, temperature fluctuations, harvesting or slaughtering. However, in case of fisheries, the welfare is associated with pre-harvesting (pre-slaughtering) and slaughtering procedures. Stressful conditions result in biochemical changes in plasma followed by the texture and nutritional value changes in. Due to stress, the physical movement of muscles will be increased, the energy sources (mainly adenosine triphosphate (ATP)) are depleted, and lactic acid in muscles increased which can drop the post mortem pH levels in muscle. In addition, there is a relationship between fish welfare and food safety risk for consumers. Due to the stress, the intestinal microflora change, which the pathogenic bacteria can be colonized which the safety of the final products can be influenced. Understanding the biochemical and physical changes during the fish harvesting and slaughtering can provide this opportunity for industry to control the stressful conditions to provide high quality seafood products with higher nutritional value and safer product. In this review, the effect of stress on fish quality, nutritional value and safety are presented.

Keywords: Fish; Welfare; Biochemical Changes; Quality; Safety

\section{Introduction}

2012 estimates put the global production of fisheries and aquaculture at $158 \mathrm{mmt}$, with $91.3 \mathrm{mmt}$ of that amount credited to capture and fisheries [1]. Recently, fish welfare has been gaining interest from both consumers and the fisheries industry (producers) concerning the production, processing, quality, shelf life and nutritional value [2]. Technically, it is difficult to define and measure the welfare of fish in fisheries. 


\section{International Journal of Oceanography \& Aquaculture}

According to [3], welfare is defined as "the balance between positive and negative experiences or affective states. The state of this balance may range from positive (good welfare) to negative (bad welfare)." In the case of fisheries, good welfare means good production at the end of the fish's life, and is determined by the handling of two important processes: the pre-slaughter procedure and the final slaughter method employed. If these two steps are conducted in bad conditions, fish will experience stress which can strongly impact their quality and nutritional value. However, there are instructions, rules and methods for terrestrial animal welfare and humane slaughtering, even if they haven't been effectively made available.

\section{History of Animal Welfare in USA}

The first attempts at humane slaughtering and improved animal welfare practices date back to the late 1800s when several new organizations were established in the United States, many linked to the Society for the Prevention of Cruelty to Children, which was founded by Mary Ellen Wilson in 1873. Four years later in 1877, representatives from 27 humane organizations in 10 states gathered for a meeting that ultimately resulted in the founding of the American Humane Association. Instantly, that association began to address inhumane treatment of farm animals. The American Humane Association, now a national non-profit organization dedicated to addressing the welfare of both children and animals, has continued the fight ever since. Its mission is to prevent cruelty, abuse, neglect, and the exploitation of children and animals, and to ensure that their interests and well-being are humanely guaranteed by an aware and caring society.

- On October 9, 1877, the first national humane organization, the American Humane Association, was established in Cleveland, Ohio by representatives from 10 states. The primary aim was to guarantee humane treatment for farm animals and livestock.

- In 1894, the link between violence against animals and violence against people was first identified.

- In 1898, under the pressure from the American Humane Association, Congress banned the practice of vivisection in schools.

- In 1915, the American Humane Association initiated a movement called Be Kind to Animals. It is still celebrated nationally during the first full week of May.
- In 1916, the American Humane Association was invited by the U.S. Secretary of War to develop humane rules for Army animals similar to those the American Red Cross employs in its treatment of soldiers. Hence, the American Red Star Animal Relief was developed to rescue wounded animals in World War I.

- In 1920, the Red Star program initiated the rescue of animals caught in disasters, and started fundraising to save and provide for thousands of elk in Yellowstone National Park.

- In 1925, the American Humane Association started a committee to address animal cruelty during animal training.

- In 1935, the American Humane Association began a study aimed at banning the application of toxic chemicals to control predatory animals. Following an incident which caused 1400 lambs to freeze to death during transportation, the Association pressured both the Interstate Commerce Commission and Bureau of Industry to protect livestock during shipping.

- In 1937, the American Humane Association's Red Star rescued and fed animals from a flood near the Mississippi River.

- In 1940, after filming "Jesse James" in 1939, a film in which a horse was killed, the American Humane Association opened a new Western Regional Office in Hollywood, California. The office work to stop cruelty to animals in film and television specifically. President Franklin D. Roosevelt signed a law protecting the bald eagle.

- In 1941, following the US entry into World War II, the American Humane Association's Red Star trained more than 400 civilians in the use of animal aids while providing millions of copies of Air Raid Precaution and Wartime Diet for Pets.

- In 1946, due to the strike by railroad workers which caused many animals to be temporarily transported in inhumane conditions, the American Humane Association volunteered to provide food and water for a number of animals.

- In 1951, the first "stamp of approval" was developed by the American Humane Association's Western 


\section{International Journal of Oceanography \& Aquaculture}

Regional Office. It certified films as practicing humane methods with regard to its animal actors.

- In 1952, using animals as test subjects in a cigarette study was banned.

- In 1958, the Humane Slaughter Act was signed into law requiring animals to be stunned unconscious prior to slaughter.

- In 1959, The Royal SPCA in England and the American Humane Association in the US developed an international society for the animal protection.

- In 1966, the American Humane Association helped prevent pets from being stolen and used as research test subjects.

- In 1970, overcrowding of animals was banned.

- In 1976, more protections were added to animal transportation protocols, providing more humane conditions.

- In 1977, the American Humane Association celebrated its centennial.

- In 1984, the first National Horse Abuse Investigation School was established.

- In 1988, the first formalized guidelines for animal welfare in the film industry were issued.

- In 1990, the first National Cruelty Investigation School for animals was initiated.

- In 1991, guidelines were developed for the welfare of those pets belonging to military reservist sent to the Middle East during the Operation Desert Storm.

- In 1998, No Animals Were Harmed website was started.

- In 1999, guidelines were developed for advertising agencies that use animals in advertisements.

- In 2000, the farm animals program was initiated by the American Humane Association to establish standards for the treatment of animals in agriculture.
- In 2011, the Animal Welfare Research Institute was established to study the methods for improving the quality of life for animals.

The act passed by Congress in 1958 (P.L. 85-765; 7 U.S.C. 1901 et seq), details what qualifies as "humane slaughtering," saying:

"No method of slaughtering or handling in connection with slaughtering shall be deemed to comply with the public policy of the United States unless it is humane.

Either of the following two methods of slaughtering and handling are hereby found to be humane:

(a) In the case of cattle, calves, horses, mules, sheep, swine, and other livestock, all animals are rendered insensible to pain by a single blow or gunshot or an electrical, chemical or other means that is rapid and effective, before being shackled, hoisted, thrown, cast, or cut; or

(b) By slaughtering in accordance with the ritual requirements of the Jewish faith or any other religious faith that prescribes a method of slaughter whereby the animal suffers loss of consciousness by anemia of the brain caused by the simultaneous and instantaneous severance of the carotid arteries with a sharp instrument and handling in connection with such slaughtering."

Meanwhile, many states have their own rules and regulations. In Table 1 , different states' rules are presented with date of enactment, methods, religious exemptions, animals covered and penalty.

Technically, animal welfare practices and slaughtering techniques are linked to the quality of the end product. Like terrestrial animals, fish should be stunned before and during slaughter to decrease fear, stress, and movement, as well as to increase the welfare and quality of the product [4]. 


\begin{tabular}{|c|c|c|c|c|c|}
\hline State & Citation & $\begin{array}{c}\text { Date } \\
\text { Enacted }\end{array}$ & Allowed Methods & Animals Covered & Penalty \\
\hline $\mathbf{A Z}$ & $\begin{array}{l}\text { AZ ST } § 3- \\
2002- \\
2017\end{array}$ & 1956 & $\begin{array}{l}\text { Single blow or gunshot or } \\
\text { an electrical, chemical or } \\
\text { other means that is rapid } \\
\text { and effective. }\end{array}$ & $\begin{array}{l}\text { Cattle, calves, horses, } \\
\text { mules, sheep, swine, } \\
\text { and other livestock. }\end{array}$ & $\begin{array}{l}\text { No penalty is listed under } \\
\text { the humane slaughter } \\
\text { statute }\end{array}$ \\
\hline CA & $\begin{array}{l}\text { CA FOOD \& } \\
\text { AG § } 19501 \\
-19503\end{array}$ & 1967 & $\begin{array}{l}\text { Captive bolt, gunshot, } \\
\text { electrical or chemical } \\
\text { means, }\end{array}$ & $\begin{array}{c}\text { All cattle, calves, } \\
\text { horses, mules, sheep, } \\
\text { swine, goats, or fallow } \\
\text { deer }\end{array}$ & $\begin{array}{l}\text { Not listed in laws, but may } \\
\text { be in rules }\end{array}$ \\
\hline CO & $\begin{array}{l}\text { CO ST § } 35- \\
33-203- \\
407\end{array}$ & $\begin{array}{c}1989 \\
\text { Note: } \\
\text { this } \\
\text { section } \\
\text { is } \\
\text { repealed } \\
\text { July 1, } \\
2009 \\
\text { pursuant } \\
\text { to } \S 35- \\
33-407 \\
\end{array}$ & $\begin{array}{l}\text { Method whereby an animal } \\
\text { is rendered insensible to } \\
\text { pain by a mechanical, } \\
\text { electrical, chemical, or other } \\
\text { means that is rapid and } \\
\text { effective. } \\
\text { Cannot use a manually } \\
\text { operated hammer, sledge, } \\
\text { or poleax. }\end{array}$ & $\begin{array}{l}\text { "Livestock" means } \\
\text { cattle, calves, sheep, } \\
\text { swine, horses, mules, } \\
\text { goats }\end{array}$ & $\begin{array}{c}\text { In addition to criminal } \\
\text { penalties prescribed, } \\
\text { violation incurs a civil } \\
\text { penalty of not more than } \\
\$ 750 \text { per violation for each } \\
\text { day of violation. }\end{array}$ \\
\hline FL & $\begin{array}{l}\text { F. S. A. § } \\
828.22\end{array}$ & 1961 & $\begin{array}{l}\text { A method whereby the } \\
\text { animal is rapidly and } \\
\text { effectively rendered } \\
\text { insensitive to pain by } \\
\text { electrical or chemical means } \\
\text { or by a penetrating captive } \\
\text { bolt or gunshot with } \\
\text { appropriate caliber and } \\
\text { placement. }\end{array}$ & $\begin{array}{c}\text { "Livestock" means } \\
\text { cattle, calves, sheep, } \\
\text { swine, horses, mules, } \\
\text { goats, ostriches, rheas, } \\
\text { emus }\end{array}$ & $\begin{array}{l}\text { Any person who violates } \\
\text { the Act and any associated } \\
\text { rule is subject to an } \\
\text { administrative fine of up to } \\
\$ 10,000 \text { for each violation. }\end{array}$ \\
\hline IA & $\begin{array}{l}\text { IA ST § } \\
\text { 189A.18- } \\
\text { 189A.22 }\end{array}$ & 1965 & $\begin{array}{l}\text { Limited to slaughter by } \\
\text { shooting, electrical shock, } \\
\text { captive bolt, or use of } \\
\text { carbon dioxide gas. }\end{array}$ & $\begin{array}{l}\text { "Livestock" means } \\
\text { alive or dead animal } \\
\text { which is limited to } \\
\text { cattle, sheep, swine, } \\
\text { goats, farm deer }\end{array}$ & $\begin{array}{l}\text { Any person who violates } \\
\text { any provisions of this } \\
\text { chapter for which no other } \\
\text { criminal penalty is } \\
\text { provided shall be guilty of a } \\
\text { simple misdemeanor. }\end{array}$ \\
\hline IL & $\begin{array}{l}\text { IL ST CH } \\
510 \S \\
75 / 0.01- \\
75 / 8\end{array}$ & 1967 & $\begin{array}{l}\text { A method whereby the } \\
\text { animal is rendered } \\
\text { insensible to pain by } \\
\text { gunshot or by mechanical, } \\
\text { electrical, chemical or other } \\
\text { means that is rapid and } \\
\text { effective. }\end{array}$ & $\begin{array}{l}\text { Cattle, calves, sheep, } \\
\text { swine, horses, mules, } \\
\text { goats, and any other }\end{array}$ & $\begin{array}{c}\text { Any violation of this Act or } \\
\text { of the rules and regulations } \\
\text { is a petty offense. }\end{array}$ \\
\hline IN & $\begin{array}{l}\text { IN ST 15- } \\
2.1-24-1- \\
15-2.1-24- \\
\quad 33\end{array}$ & 1996 & $\begin{array}{c}\text { State board establishes } \\
\text { rules that require animals to } \\
\text { be rendered insensible to } \\
\text { pain prior to severance of } \\
\text { the carotid artery. }\end{array}$ & $\begin{array}{l}\text { Livestock and poultry } \\
\text { (according to the } \\
\text { Purpose of Chapter, } \\
\text { Sec. 15-2.1-24-1(3)). }\end{array}$ & $\begin{array}{l}\text { A person who recklessly } \\
\text { violates this chapter } \\
\text { commits a Class B } \\
\text { misdemeanor. }\end{array}$ \\
\hline KS & $\begin{array}{c}\text { KS ST § 47- } \\
1401- \\
\end{array}$ & 1961 & $\begin{array}{l}\text { A method whereby the } \\
\text { animal is rendered }\end{array}$ & $\begin{array}{l}\text { Cattle, calves, sheep, } \\
\text { swine, horses, mules, }\end{array}$ & $\begin{array}{c}\text { Misdemeanor (exact terms } \\
\text { not specified). }\end{array}$ \\
\hline
\end{tabular}




\section{International Journal of Oceanography \& Aquaculture}

\begin{tabular}{|c|c|c|c|c|c|}
\hline & 1405 & & $\begin{array}{l}\text { insensible to pain by } \\
\text { mechanical, electrical, } \\
\text { chemical, or other means } \\
\text { that is rapid and effective. }\end{array}$ & goats, aquatic animals & \\
\hline MD & $\begin{array}{l}\text { MD Code, } \\
\text { Agriculture, } \\
\S 4-101- \\
4-131\end{array}$ & 2002 & $\begin{array}{l}\text { A method by which } \\
\text { livestock are rendered } \\
\text { insensible to pain, by a } \\
\text { single blow or gunshot, or } \\
\text { by an electrical, chemical, or } \\
\text { other rapid and effective. } \\
\text { Humane method" does not } \\
\text { include the use of a } \\
\text { manually operated hammer, } \\
\text { sledge, or poleax during a } \\
\text { slaughtering operation. }\end{array}$ & $\begin{array}{l}\text { "Livestock" means } \\
\text { cattle, calves, sheep, } \\
\text { swine, horses, mules, } \\
\text { goats, or other } \\
\text { animals that may be } \\
\text { used in the } \\
\text { preparation of a meat } \\
\text { product. } \\
\text { "Livestock" does not } \\
\text { include poultry or } \\
\text { other fowl. }\end{array}$ & $\begin{array}{l}\text { A person who violates this } \\
\text { section is guilty of a } \\
\text { misdemeanor and on } \\
\text { conviction is subject to a } \\
\text { fine not exceeding } \$ 100 \text { for } \\
\text { each violation. The } \\
\text { Secretary may refuse to } \\
\text { provide or may suspend } \\
\text { temporarily inspection } \\
\text { services for an } \\
\text { establishment that violates } \\
\text { this section with respect to } \\
\text { the slaughter of livestock. }\end{array}$ \\
\hline ME & $\begin{array}{c}\text { ME ST T.22 } \\
\S 2521- \\
2521-\mathrm{C}\end{array}$ & 1999 & $\begin{array}{c}\text { Rendering animals } \\
\text { insensible to pain by a } \\
\text { single blow or gunshot or an } \\
\text { electrical, chemical or other } \\
\text { means that is rapid and } \\
\text { effective. }\end{array}$ & $\begin{array}{l}\text { Limited to "livestock" } \\
\text { which is not defined in } \\
\text { the section. }\end{array}$ & $\begin{array}{l}\text { Not specified/no penalty } \\
\text { given. }\end{array}$ \\
\hline MI & $\begin{array}{c}\text { MCL } \S \\
287.551\end{array}$ & 1962 & $\begin{array}{l}\text { A method whereby the } \\
\text { animal is rendered } \\
\text { insensible to pain by } \\
\text { mechanical, electrical, } \\
\text { chemical or other means } \\
\text { that is rapid and effective. } \\
\\
\text { The use of a manually } \\
\text { operated hammer, sledge or } \\
\text { poleax is declared to be an } \\
\text { inhumane method of } \\
\text { slaughter within the } \\
\text { meaning of this act. }\end{array}$ & $\begin{array}{l}\text { "Livestock" means } \\
\text { cattle, calves, sheep, } \\
\text { swine, horses, mules, } \\
\text { goats and any other } \\
\text { animal which can or } \\
\text { may be used in and for } \\
\text { the preparation of } \\
\text { meat or meat } \\
\text { products. }\end{array}$ & $\begin{array}{l}\text { Any person who violates } \\
\text { any provision of this act } \\
\text { shall be guilty of a } \\
\text { misdemeanor. }\end{array}$ \\
\hline MN & $\begin{array}{c}\text { MN ST § } \\
31.59- \\
31.592\end{array}$ & 1961 & $\begin{array}{l}\text { Any method of slaughtering } \\
\text { livestock which normally } \\
\text { causes animals to be } \\
\text { rendered insensible to pain } \\
\text { by a single blow of a } \\
\text { mechanical instrument or } \\
\text { shot of a firearm or by } \\
\text { chemical, or other means } \\
\text { that are rapid and effective. } \\
\text { The use of a manually } \\
\text { operated hammer or sledge } \\
\text { is declared an inhumane } \\
\text { method of slaughter. }\end{array}$ & $\begin{array}{l}\text { "Livestock" means } \\
\text { cattle, horses, swine, } \\
\text { sheep and goats. }\end{array}$ & $\begin{array}{l}\text { A person violation the Act } \\
\text { is guilty of a misdemeanor } \\
\text { and shall be punished } \\
\text { accordingly. }\end{array}$ \\
\hline NH & $\begin{array}{l}\text { NH ST § } \\
427: 33-\end{array}$ & 1960 & $\begin{array}{l}\text { Any method of slaughtering } \\
\text { livestock which normally }\end{array}$ & $\begin{array}{l}\text { "Livestock" means } \\
\text { cattle, horses, swine, }\end{array}$ & Unspecified Misdemeanor. \\
\hline
\end{tabular}




\section{International Journal of Oceanography \& Aquaculture}

\begin{tabular}{|c|c|c|c|c|c|}
\hline & 37 & & $\begin{array}{l}\text { causes animals to be } \\
\text { rendered insensible to pain } \\
\text { by a single blow or shot of a } \\
\text { mechanical instrument or } \\
\text { by electrical, chemical or } \\
\text { other means that is rapid } \\
\text { and effective. }\end{array}$ & $\begin{array}{l}\text { sheep, goats, as well as } \\
\text { domesticated strains } \\
\text { of buffalo, bison, } \\
\text { llamas, alpacas, emus, } \\
\text { ostriches, yaks, elk } \\
\text { (cervus elephus } \\
\text { canadensis), fallow } \\
\text { deer (dama dama), } \\
\text { red deer (cervus } \\
\text { elephus), reindeer } \\
\text { (Rangifer taradus), } \\
\text { and other species of } \\
\text { animals susceptible of } \\
\text { use in the production } \\
\text { of meat and meat } \\
\text { products. }\end{array}$ & \\
\hline NJ & $\begin{array}{l}\text { NJ ST } 4: 22- \\
1 \text { et seq. }\end{array}$ & 1968 & $\begin{array}{l}\text { Not specified in the } \\
\text { Act. Provides that the State } \\
\text { Board of Agriculture shall } \\
\text { develop and adopt (1) } \\
\text { standards for the humane } \\
\text { raising, keeping, care, } \\
\text { treatment, marketing, and } \\
\text { sale of domestic livestock; } \\
\text { and (2) rules and } \\
\text { regulations governing the } \\
\text { enforcement of those } \\
\text { standards. }\end{array}$ & $\begin{array}{l}\text { For the purposes of } \\
\text { this act, "domestic } \\
\text { livestock" means } \\
\text { cattle, horses, } \\
\text { donkeys, swine, sheep, } \\
\text { goats, rabbits, poultry, } \\
\text { fowl, and any other } \\
\text { domesticated animal } \\
\text { deemed by the State } \\
\text { Board of Agriculture } \\
\text { and the Department of } \\
\text { Agriculture. }\end{array}$ & $\begin{array}{l}\text { No person may be cited or } \\
\text { arrested for a first offense } \\
\text { involving a minor or } \\
\text { incidental violation, as } \\
\text { defined by rules and } \\
\text { regulations unless that } \\
\text { person has first been } \\
\text { issued a written warning. }\end{array}$ \\
\hline $\mathbf{O H}$ & $\begin{array}{l}\text { OH ST § } \\
945.01- \\
945.99\end{array}$ & 1965 & $\begin{array}{l}\text { In the case of cattle, calves, } \\
\text { horses, mules, sheep, swine, } \\
\text { and other livestock, all } \\
\text { animals are rendered } \\
\text { insensible to pain by a } \\
\text { single blow or gunshot or an } \\
\text { electrical, chemical, or other } \\
\text { means that is rapid and } \\
\text { effective. }\end{array}$ & $\begin{array}{l}\text { Cattle, calves, horses, } \\
\text { mules, sheep, swine, } \\
\text { and other livestock }\end{array}$ & $\begin{array}{l}\text { Subject to fine not more } \\
\text { than one hundred dollars } \\
(\$ 100) .\end{array}$ \\
\hline OR & $\begin{array}{c}\text { OR ST § } \\
603.010- \\
603.992\end{array}$ & 1973 & $\begin{array}{l}\text { Renders each such animal } \\
\text { insensible to pain by a } \\
\text { single blow or gunshot or by } \\
\text { an electrical, chemical or } \\
\text { other means that is rapid } \\
\text { and effective. }\end{array}$ & $\begin{array}{l}\text { Cattle, equines, sheep } \\
\text { or swine. }\end{array}$ & $\begin{array}{l}\text { Violation of ORS } 603.065 \\
\text { (the humane slaughter } \\
\text { law) is a Class B } \\
\text { misdemeanor. }\end{array}$ \\
\hline PA & $\begin{array}{l}\text { PA ST } 3 \\
\text { Pa.C.S.A. § } \\
2361\end{array}$ & 1996 & $\begin{array}{c}\text { Humane methods are } \\
\text { required, but } \\
\text { undefined. However, the } \\
\text { use of a manually operated } \\
\text { hammer, sledge or poleax } \\
\text { by slaughterers, packers or } \\
\text { stockyard operators during } \\
\text { slaughtering operations is }\end{array}$ & $\begin{array}{c}\text { The term livestock is } \\
\text { undefined. }\end{array}$ & $\begin{array}{l}\text { Not listed in the law, but } \\
\text { may be provided by } \\
\text { departmental regulations. }\end{array}$ \\
\hline
\end{tabular}




\section{International Journal of Oceanography \& Aquaculture}

\begin{tabular}{|c|c|c|c|c|c|}
\hline & & & $\begin{array}{c}\text { not a humane method of } \\
\text { slaughter. }\end{array}$ & & \\
\hline RI & $\begin{array}{c}\text { RI ST § 4- } \\
17-1-4- \\
17-7\end{array}$ & 1961 & $\begin{array}{l}\text { A method through which } \\
\text { the animal is rendered } \\
\text { insensible to pain by } \\
\text { mechanical, electrical, } \\
\text { chemical or other means } \\
\text { that is rapid and effective. }\end{array}$ & $\begin{array}{l}\text { Cattle, cows, sheep, } \\
\text { swine, horses, mules, } \\
\text { goats and any other } \\
\text { animal which can or } \\
\text { may be used in and for } \\
\text { the preparation of } \\
\text { meat or meat } \\
\text { products. }\end{array}$ & $\begin{array}{l}\text { Subject to a fine of not } \\
\text { more than five hundred } \\
(\$ 500) \text { dollars, or by } \\
\text { imprisonment for not more } \\
\text { than one year. }\end{array}$ \\
\hline VT & $\begin{array}{l}\text { VT ST T. } 6 \S \\
3131- \\
3134\end{array}$ & 1987 & $\begin{array}{l}\text { A method whereby the } \\
\text { animal is rendered } \\
\text { insensible to pain by } \\
\text { mechanical, electrical, } \\
\text { chemical or other means } \\
\text { that is rapid and effective. }\end{array}$ & $\begin{array}{l}\text { "Livestock" means } \\
\text { cattle, calves, sheep, } \\
\text { swine, horses, mules, } \\
\text { goats, fallow deer, } \\
\text { American bison and } \\
\text { any other animal } \\
\text { which can or may be } \\
\text { used in and for the } \\
\text { preparation of meat or } \\
\text { meat products. }\end{array}$ & $\begin{array}{l}\text { A person who violates this } \\
\text { chapter shall be fined not } \\
\text { more than } \$ 100.00 \text { nor less } \\
\text { than } \$ 50.00 \text {. }\end{array}$ \\
\hline WA & $\begin{array}{c}\text { West's } \\
\text { RCWA } \\
16.50 .010- \\
16.50 .900\end{array}$ & 1967 & $\begin{array}{l}\text { A method whereby the } \\
\text { animal is rendered } \\
\text { insensible to pain by } \\
\text { mechanical, electrical, } \\
\text { chemical or other means } \\
\text { that is rapid and effective. } \\
\text { The use of a manually } \\
\text { operated hammer, sledge or } \\
\text { poleaxe is declared to be an } \\
\text { inhumane method of } \\
\text { slaughter. }\end{array}$ & $\begin{array}{l}\text { "Livestock" means } \\
\text { cattle, calves, sheep, } \\
\text { swine, horses, mules } \\
\text { and goats. }\end{array}$ & $\begin{array}{l}\text { A misdemeanor and } \\
\text { subject to a fine of not } \\
\text { more than two hundred } \\
\text { fifty dollars or confinement } \\
\text { in the county jail for not } \\
\text { more than ninety days. }\end{array}$ \\
\hline WV & $\begin{array}{c}\text { WV ST § } \\
19-2 \mathrm{E}-1- \\
19-2 \mathrm{E}-7\end{array}$ & 1982 & $\begin{array}{l}\text { Livestock, before being } \\
\text { shackled, hoisted, thrown, } \\
\text { cast or cut must be } \\
\text { rendered insensible to pain } \\
\text { by a single blow, gunshot or } \\
\text { by electrical, chemical or } \\
\text { other means that is safe, } \\
\text { rapid and effective. }\end{array}$ & $\begin{array}{l}\text { Cattle, swine, sheep or } \\
\text { goats. }\end{array}$ & $\begin{array}{l}\text { The section provides a } \\
\text { graduating scheme of } \\
\text { penalties for violation: } \\
\text { - a first offense results in a } \\
\text { misdemeanor punishable } \\
\text { by a fine of } \$ 100 \text { - } \$ 500 \text {. } \\
\text { - a second offense results in } \\
\text { a misdemeanor with a fine } \\
\text { of } \$ 500 \text { - } \\
\text { 1,000and suspension of the } \\
\text { license }\end{array}$ \\
\hline
\end{tabular}

Table 1: The States' Animal Slaughtering Rules (Adopted from Animal Legal \& Historical Center, 2006). 


\section{International Journal of Oceanography \& Aquaculture}

\section{Welfare measurement}

As discussed above, the definition of welfare is not clear or straightforward [2]. There are two major issues when it comes to defining and measuring animal welfare [5-9]. Generating appropriate guidelines for animal welfare depends on resolving these issues. There are differences between terrestrial animals and fish, but the five freedoms developed in the UK regarding terrestrial animals could easily be applied to fish. The five freedoms include freedom from hunger and thirst, freedom from discomfort, freedom from pain, injury, and disease, freedom to express normal behavior and freedom from fear and distress [9]. All five could easily be applied to fish from aquaculture. However, for those harvesting from natural resources like fisheries, it's more complicated. The five freedoms are applied as a scientifically accurate index for measuring animal welfare [9]. For example, by periodically checking the environment of animals and their physical status within it, their welfare could be determined. However, good animal welfare can go beyond the physical aspects and includes mental changes, which is more complicated when it comes to fish [9]. The concept of animal welfare has been applied to those animals we believe can feel and experience pain, fear, stress and suffering. There is scientific evidence that fish also experience and feel pain, stress and suffering, and that they respond to the stressors in physical, behavioral and physiological scales [10-12]. Therefore, when fish respond to the stressors, it is hypothetically possible to measure their state of welfare.

\section{Response to Stress}

The response to stress starts in the brain and is closely followed by biochemical changes in the blood and subsequent behavioral changes. In aquaculture, the stress could be related to fish crowding, feeding, handling, disease, transportation, drug administration, water quality, temperature fluctuations, harvesting or slaughtering. However, when it comes to fisheries, the stressful conditions are related to pre-harvesting (preslaughtering) and slaughtering procedures.The response to stress starts with the release of catecholamines and activation of the hypothalamic-pituitary-interrenal (HPI) axis. Then, corticotropin released from the hypothalamus stimulates the pituitary gland to synthesize and release corticotropic hormones, which then stimulates the synthesis and mobilization of lipid and glucocorticoid hormones (cortisol in teleosts) from the interrenal cells $[13,14]$. The energy source mobilization includes the lipid, so changes in plasma-free fatty acids (FFA) could be a stress condition index if not for the fact that the parameter generally does not show a clear response [2]. Secondary and tertiary stress responses, as well as many adverse changes in the quality of the fish, will be initiated by both catecholamines andcortisol [15].

HPI activation results in energy source mobilization, depletion of glycogen stores, and an increase in plasma levels of glucose, along with high muscle activity which can cause anaerobic glycolysis and, as a result, an increase in plasma lactate and a big drop in muscle $\mathrm{pH}$. Therefore, the levels of blood cortisol, glucose and lactate are often used to assess stress levels [16-18]. It has been shown that through diet modulation, and the use of supplements like vitamin $\mathrm{C}$ and vitamin $\mathrm{E}$, the fish's resistance to stressors will be increased [19-21]. It cannot, however, be applied for the fisheries industry.

Catecholamines (adrenaline and noradrenaline) are not commonly used as stress indicators because they are not easy to determine and are quickly removed from the blood [14]. Cortisol is widely used as both a long-term and short-term stress condition index [22,23]. While under stress, heart rate will increase and the need for greater oxygen intake will cause a boost in the number of moving erythrocytes and of the hematocrit value, which can also being used as an indicator for stress.A rapid death does not allow a completion of the secondary effects of stress, and pre-slaughter stress always has to be considered in the stress evaluation at slaughter by the hematic parameters.

\section{The effect of Stress on Fish Quality and Nutritional Value}

Along with the biochemical changes in plasma due to stress, the texture and nutritional value of the final product will also be adversely influenced by stress and inhumane harvesting practices. Due to stress, the physical movement of muscles will be increased, depleting energy sources, mainly adenosine triphosphate (ATP), and, as discussed above, increasing the lactic acid in muscles and dropping their post mortem $\mathrm{pH}$ levels. Hence, those fish which face stressful conditions during harvesting go into rigor mortis rapidly, which negatively effects the quality of the fillets with drip loss and a softening of the muscle texture [24-29]. Harvesting time is critical for fish in terms of stress, and the amount of stress experienced by a fish depends heavily on the duration, struggle and crowding of the harvesting process. Labored swimming during harvesting causes an intense use of white muscles and results in anaerobic glycolysis followed by increase in lactic acid and less muscle $\mathrm{pH}$ (Figure 1). 


\section{International Journal of Oceanography \& Aquaculture}

In contrast, in humanely slaughtered fish, the reduction of stress means that only some muscles will enter rigor mortis while others do not. This difference in timing results in a higher quality fillet in terms of texture. Another physical attribute that can change with harvesting techniques is the color of the fillet. It has been shown that pre-harvesting and harvesting stress significantly affects salmonids fillet color $[30,31]$ which may be due to the insolubilization of muscle proteins as a result of low $\mathrm{pH}$ and drip loss that occurs in the development of prerigor and rigor mortis [32].

In addition, harvesting and post harvesting stress exposes the flesh of fish to the oxidation of polyunsaturated fatty acids (PUFAs), which can result in the production of reactive oxygen metabolites (ROMs). The production of ROMs is proven to induce severe damage in nucleic acid, proteins and lipids, and act as a carcinogen leading to inflammation, glomerular disease and aging for consumers [29,33-36]. In fish with a low level of activity, only some muscles have been used. These are the first muscles to enter rigor mortis, while the others do so later. Because of this difference in timing, not all muscles enter rigor mortis at the same time, so the fish as a whole is less stiff [37]. What's more, stress conditions in harvesting and post harvesting processes can induce peroxidase and aldehyde production in the fish fillet during short storage, which can decrease the nutritional quality of the fish fillet. As a result, the nutrient quality will be decreased, as well as both the texture and flavor of the product due to the degradation and loss of fatty acids and protein. Hence, at the end of the procedure, both physical and nutritional quality will be altered by stress which can influence the marketing to health-conscious consumers. Bagni et al. (2007) [29] found that the ROM was higher in sea bass subjected to stress compared with those kept in normal conditions.

One of the major reasons for seafood consumption, particularly marine harvested fish from fisheries, is obtaining the high quality protein and PUFAs. Fish PUFAs have several benefits for humans. They include the ability to decrease blood triglyceride counts, cure rheumatoid arthritis, boostthe effects of antidepressants and combat the depressive symptoms of bipolar disorder. They also help develop the visual and neurological faculties in infants, improve the cognition in children with Attention Deficit Hyperactivity Disorder (ADHD), protect against Alzheimer's disease and reduce the risk of ischemic stroke, particularly in older people.

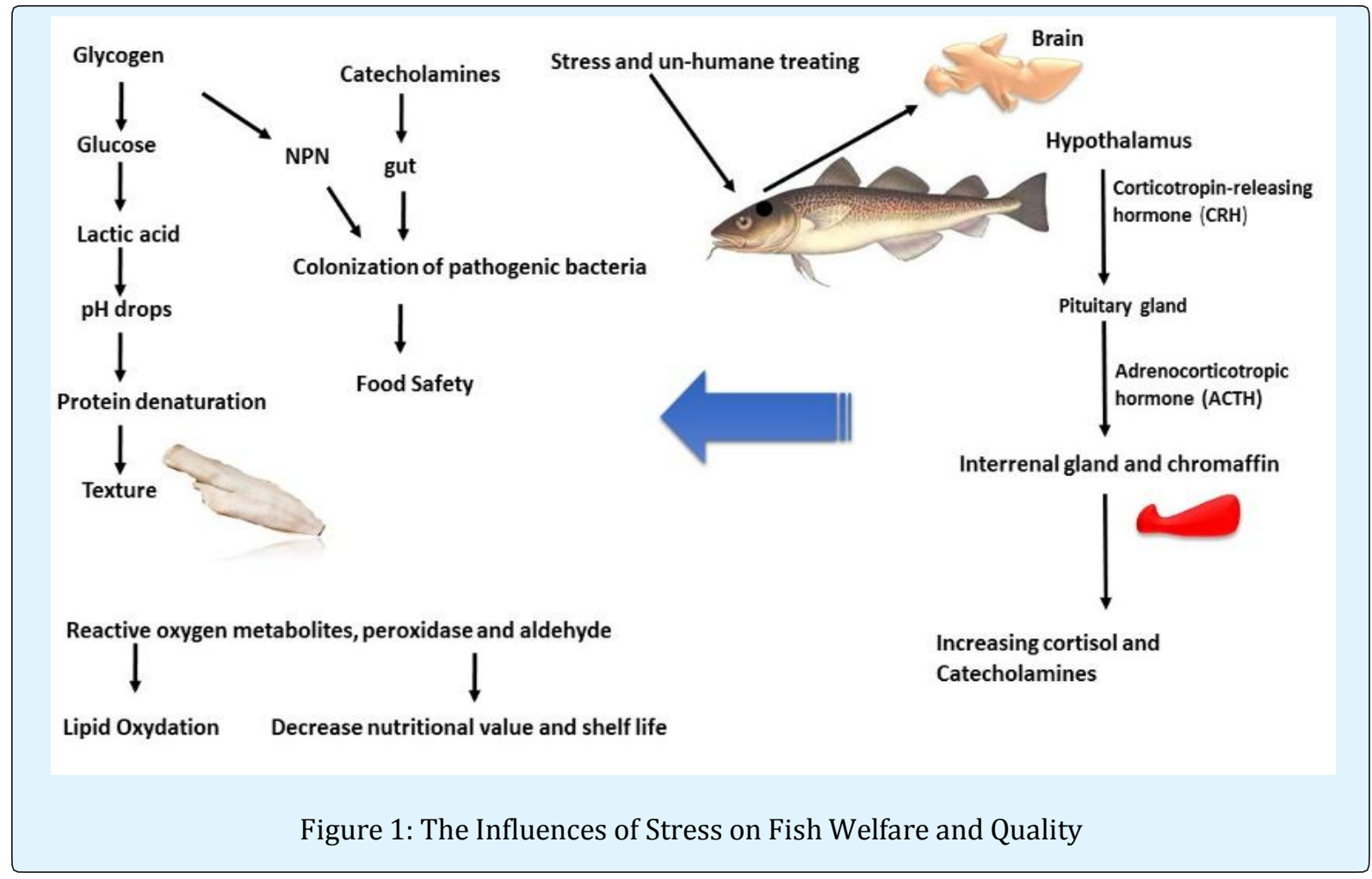

Ovissipour M, Humane Harvesting Initiative: The Influence of Humane Harvesting on Fish Quality, Nutritional Value and Safety. Int J Ocea Aqua, 


\section{International Journal of Oceanography \& Aquaculture}

\section{The Relationship between Stress and Food Safety Risk}

The relationship between stress and food safety risk has been studied by researchers in animal science. They have found that there is a link between stress and pathogenic bacteria which can increase the food safety risk for humans. The gastrointestinal tract is the main habitat of different bacteria, including both useful and pathogenic bacteria. Technically, the nervous system is controlling the digestive tracts microcirculation, motility and secretions - this is called the brain-gut axis. Since, the first response to stress starts in the brain, it can influence functional and inflammatory disorders as well as infection. Catecholamine hormones particularly norepinephrine are normally presented in the gastrointestinal tract. However, during the stress period, the nervous system of the digestive tract releases catecholamines, causing significant local increases. This increase can strongly influence the intestinal microbial populations. The pathogen can colonize through different methods following stress, including suppression of the immune system, and promoting physiological alterations in the gastrointestinal tract, increasing their virulence and multiplication rate in the gut. Consequently, exposure of farm animals to stressors will lead to increased levels of foodborne pathogens in the gastrointestinal tract and increased risk of contamination of their carcasses [38]. This is important for farmed animals and aquaculture sectors, but it's worthwhile to predict the stressful conditions in pre-harvesting procedure which might include crowding, duration, and fish movement.

The influences of the stress on nutritional value and filet quality were discussed earlier, however, the preharvesting and slaughtering methods can influence the microbial growth in fillet too. In 2009, the European Food Safety Authority discussed an opinion related to the influence of farmed fish slaughtering and food safety risk relationship (EFSA 2009). After slaughtering, postmortem chemical changes begin to take place, including glycolysis, enzymatic activity, nucleotide catabolism, $\mathrm{pH}$ drop and an increase in concentration of free non-protein nitrogen (NPN) compounds. The direct relationship between post-mortem changes and fillet quality has been proven, however, these biochemical changes also influence the food safety levels. The level of glycolysis inside the fish at the time of slaughter has a direct effect on the level of NPN, with high levels supporting bacterial growth.

\section{Pre-Harvesting and Harvesting}

The term "harvesting" is related to the slaughtering of fish, while "pre-harvesting" includes all activities the fish experiences between catch and slaughter. The term "slaughter," or "slaughtering," is used in reference to the termination of an animal life for human consumption. "Euthanasia" is the term used in reference to the humane killing of an animal which is not intended for human consumption. These days, animal slaughtering is an interesting topic for both consumers and the industry, not only in terms of ethics, animal welfare and humane harvesting, but also in terms of the quality, nutritional value and consumer health. Inherently, slaughter is a highly stressful moment for fish [39]. An important part of the slaughter process is decreasing the time between harvesting and slaughtering with fast stunning. Technically, there are two slaughtering methods, fast and slow. Fast methods are being used for big fish, however, it's not always possible to apply this method for small fish. Some of the slow methods include asphixiation in air, asphixiation in ice, exsanguination, carbon dioxide narcosis, evisceration, decapitation, anesthetics, salt or ammonia bath, anoxic water bath, electro-immobilisation and electro-stimulation as well as electro-fishing [40]. These methods are slow, inhumane and do not promote improved animal welfare. The slaughtering procedure influences on fish welfare could be shown as a model (Figure 2) [41].

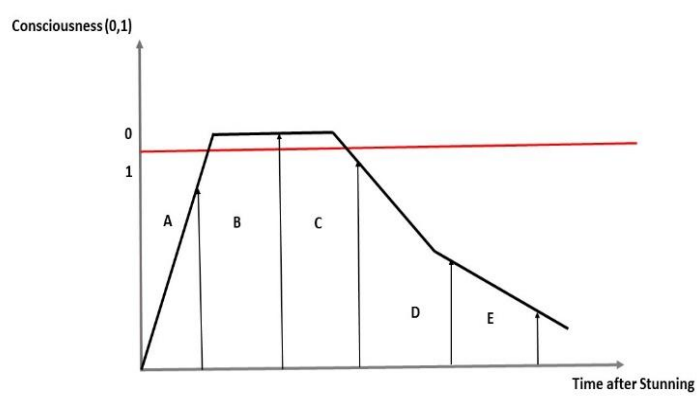

Figure 2: The Influence of Slaughtering Method on Fish Welfare Model (Adopted from Brethe, 2011).

In this model, section A shows that fish is killed in an un-humane condition in which fish is conscious, while it should be stunned before that; section B is an ideal condition, in which fish has been stunned and is killed or dies after it is unconscious; in $\mathrm{C}$ fish has been stunned but 


\section{International Journal of Oceanography \& Aquaculture}

it can recover its consciousness and shows un-humane slaughtering; in section D a fish is killed in un-welfare way such as asphyxia while it is conscious but has also suffered from the aversive nature of the stunning method; in section E fish that has been stunned and is killed or dies after it is unconscious but has also suffered from the unhumane stunning method.

\section{Asphixiation or Death in Air}

This traditional method for slaughtering fish is based on leaving fish in the air to die. It is the most stressful slaughtering method, with fish experiencing prolonged suffering before death. The death time depends on the hypoxia resistance which is based on on species and temperature.This method is inhumane and can adversely influence the fish quality and shelf life of the products.Some fish, such as eel and carp are resistant to hypoxia, however most other fish are sensitive to hypoxia conditions. Due to the higher metabolism and faster consumption of oxygen, at higher temperatures, death will occur faster once hypoxia sets in. Lower muscle $\mathrm{pH}$, faster rigor mortis and higher muscle lactate were all observed in those fish slaughtered via this method $[40,42]$.

\section{Asphixiation in Ice}

Another method for slaughtering fish is to immediately place them in ice after harvesting. Consequently, the body temperature, metabolic rate, oxygen requirement and movement will all be decreased. The death time is prolonged, however. This method is not humane. Since the death time is prolonged, fish can still feel pain, stress and fear. Hence, it is not recommended $[2,40]$.

\section{Electrical stunning and electrocution}

This method is used for fresh water fish due to the high conductivity of freshwater for stunning with electricity $[2,43]$. This method is fast, however, it can cause a violent reaction, including an open mouth and opercula as well as blood spots and other color changes along the backbone muscles. In addition, applying electricity could be harmful for workers.

\section{Bleeding or exsanguination}

Many large fish such as tuna and Atlantic salmon are subjected to bleeding by the cutting of gills or veins and left to die in the water. The most common method is bleeding after stunning, however, in many regions, producers use bleeding methods without any prestunning method [40]. Bleeding alone is a slow slaughtering method which can induce stress, pain and fear. However, the quality of the final product is high. This method, employed alone, is inhumane. According to the research, there is no scientific evidence which shows that exsanguination without stunning produces a better result than exsanguination after stunning [40]. Studies about the quality of red and white muscles showed that the bleeding of an animal without a heartbeat is similar to the bleeding with a heartbeat $[40,44,45]$. Hence, it is strongly recommended to use bleeding after stunning the fish [40]. There are other slaughtering methods which are fast and more humane, including percussive stunning, hydraulic shock, spiking, shooting and electrical stunning [40].

\section{Percussive stunning}

This is one of the most common slaughter methods used in the salmon industry, in cod and halibut fisheries, and by anglers $[40,46]$. After removing the fish from the water, a club will be immediately used, either by workers or an automatic machine, to strike the fish's brain, instantly stunning it. It has been shown that the quality of the fish fillet was higher after applying percussive stunning $[40,47]$.

\section{Hydraulic stunning}

This method uses a hydraulic device to stun the fish. However, due to the damage in muscles, the backbone, gut and gas bladder, fish quality will be negatively influenced [40]. Robb, et al.[40] compared different slaughtering methods in terms of humane practice and resulting quality (Table 2). Some of these methods have both low negative impacts on welfare and quality, however, due to some limitations their application is not appropriate. For example, using medicine for fish anesthetics is humane and has a minimal impact on the fish quality, but, due to the regulations, is not recommended. In addition, some other methods such as spiking, shooting and electrical stunning have a low negative effect on welfare and quality, but due to the difficulties in practicing, they are not appropriate methods at an industrial scale. It has been recommended that using two humane methods such as percussive stunning and bleeding not only provides the humane slaughtering aspect, but can also increase the quality of the final products due to the better texture, color and nutritional value. Each of these methods has its own advantages and limitations.

In many cases, the method can decrease the stress and increase the fish welfare, but due to the technical demands, cost, low efficiency, and extensive labor required, its application on an industrial scale is not 


\section{International Journal of Oceanography \& Aquaculture}

possible. By combining two or three methods, industry can overcome these limitations.

\begin{tabular}{|c|c|c|c|}
\hline Method 1 & $\begin{array}{c}\text { Negative Impact on } \\
\text { Welfare }\end{array}$ & $\begin{array}{c}\text { Negative Impact on } \\
\text { Quality }\end{array}$ & $\begin{array}{c}\text { Negative impact on Food } \\
\text { Safety } \\
\end{array}$ \\
\hline Asphyxiation & High & High & Low \\
\hline Asphyxiation in ice & High & Low & Low \\
\hline Exsanguination & Very High & High & High \\
\hline Carbon dioxide narcosis & High & High & Low \\
\hline Evisceration & Very High & High & High \\
\hline Decapitation & Very High & - & High \\
\hline Anesthetics & Very Low & Very Low & Very Low \\
\hline Salt or ammonia bath & Very High & High & Low \\
\hline Desliming in eel & High & High & Low \\
\hline Electro-immobilisation & Very High & Very High & Low \\
\hline Percussive stunning & Low & Low & Very Low \\
\hline Hydraulic shock & Very Low & Very High & Low \\
\hline Spiking, coring, ikejime & Low & Low & High \\
\hline Shooting & Low & Low & High \\
\hline Electrical stunning & Very Low & Low & Low \\
\hline $\begin{array}{l}\text { Combined method } \\
\text { Percussive-Bleeding }\end{array}$ & Very Low & Very Low & Low \\
\hline
\end{tabular}

Table 2: Comparison of different methods of slaughtering on fish welfare and quality.

\section{Conclusion}

Seafood is one of the most important natural vectors for high nutritional value protein and omega-3s for human. Since fish can feel pain and stress, these factors can easily influence their quality, nutritional value, shelf life and consumption safety. On the other side, the fisheries' efforts to harvest fish in ways that maintain the quality result in not only high value products for consumers, but also a decreased carbon footprint for the industry. A sustainable fisheries and seafood production chain will be established. Once the quality begins to deteriorate, it is almost impossible to reclaim. On the other hand, deterioration which includes lipid oxidation and protein denaturation is an irreversible procedure which should be controlled from the very beginning of harvesting. Some pioneering companies, like Blue North Fisheries, have developed a novel approach called "Moon Pool" as part of pre-slaughtering procedure to decrease the fish's stress before bringing the fish aboard. It seems there is a big space for humane fisheries in the seafood production supply chain to strongly improve the quality, nutritional value and safety of the final products. Sustainable fisheries practices could also provide a vantage point from which to consider animal welfare.

Ovissipour M, Humane Harvesting Initiative: The Influence of Humane Harvesting on Fish Quality, Nutritional Value and Safety. Int J Ocea Aqua, 2016, 1(1): 000101.

\section{References}

1. Food and Agriculture Organization (2014) The State of World Fisheries and Aquaculture in 2012.

2. Poli BM, Parisi G, Scappini F, Zampacallo G (2005) Fish welfare and quality affected by pre-slaughter and slaughter management. Aquaculture International 13: 29-49.

3. Spruijt BM, Van den Bos R, Pijlman FTA (2001) A concept of welfare based on reward evaluating mechanisms in the brain: anticipatory behaviour as an indicator for the state of reward systems. Appl Anim Behav Sci 72(2): 145-171.

4. Animal Legal and Historical Center (2006) Table of State Humane Slaughter Laws.

5. Broom DM (1991a) Animal welfare-concepts and measurement. J Anim Sci 69(10): 4167-4175.

6. Broom DM 1991b Assessing welfare and suffering. Behav Processes 25(2-3): 117-123.

7. Dawkins MS (1998) Evolution and animal welfare. Q Rev Biol 73(3): 305-328. 


\section{International Journal of Oceanography \& Aquaculture}

8. Mendl M, Paul ES (2004) Consciousness, emotion and animal welfare: insights from cognitive science. Animal Welfare 13(S1): 17-25.

9. Ashley PJ (2007) Fish welfare: Current issues in aquaculture. Applied Animal Behaviour Science 104(3-4): 199-235.

10. Braithwaite VA, Huntingford FA (2004) Fish and welfare: do fish have the capacity for pain perception and suffering?Animal Welfare 13(S1) 87-92.

11. Chandroo KP, Duncan IJH, Moccia RD (2004a) Can fish suffer? Perspectives on sentience, pain, fear and stress. Applied Animal Behaviour Science 86(3-4) 225-250.

12. Chandroo KP, Yue S, Moccia RD (2004b) An evaluation of current perspectives on consciousness and pain in fishes. Fish and Fisheries 5(4): 281-295.

13. Schreck CB (1981) Stress and compensation in teleostean fishes: response to social and physical factors. In: AD, P(Edn.), Stress and Fish. Academic Press, London, pp. 295-321.

14. Wendelaar-Bonga SEW (1997) The stress response in fish. Physiol Rev 77(3): 591-625.

15. Schreck CB, Contreras-Sanchez W, Fitzpatrick MS (2001) Effects of stress on fish reproduction, gamete quality, and progeny. Aquaculture 197(1-4): 3-24.

16. Arends RJ, Mancera JM, Munoz JL, Bonga SEW, Flik G (1999) The stress response of the gilthead sea bream (Sparus aurata L.) to air exposure and confinement. J Endocrinol 163(1): 149-157.

17. Acerete L, Balasch JC, Espinosa E, Josa A, Tort L (2004) Physiological responses in Eurasian perch (Perca fluviayilis L.) Subjected to stress by transport and handling. Aquaculture 237(1-4): 167-178.

18. Nikoo M, Falahatkar B, Alekhorshid M, Nematdost Haghi B, Asadollahpour A, et al. (2010) Physiological stress responses in kutum Rutilus frisii kutum subjected to captivity. International Aquatic Research 2: 55-60.

19. Dabrowska H, Dabrowski K, Meyerburgdorff K, Hanke W, Gunther KD (1991) The effect of large doses of Vitamin-C and magnesium on stress responses in Common Carp, Cyprinus-Carpio. Comp Biochem Physiol A Comp Physiol 99(4): 681-685.

Ovissipour M, Humane Harvesting Initiative: The Influence of Humane Harvesting on Fish Quality, Nutritional Value and Safety. Int J Ocea Aqua, 2016, 1(1): 000101.
20. Merchie G, Lavens P, Verreth J, Ollevier F, Nelis H, et al. (1997) The effect of supplemental ascorbic acid in enriched live food for Clarias gariepinus larvae at startfeeding. Aquaculture 151: 245-258.

21. Abedian Kennari A, Ovissipour M, Nazari RM (2007) Effects of n3-HUFA enriched Daphnia magna on growth, survival, stress resistance, and fatty acid composition of larvae of Persian sturgeon (Acipenser persicus). Iranian Journal of Fisheries Science 7(1): 114.

22. Pickering AD, Pottinger TG, Christie P (1982) Recovery of the brown trout, Salmo trutta L., from acute handling stress: a time-course study. Journal of Fish Biology 20(2): 229-244.

23. Pickering AD, Pottinger TG (1985) Factors influencing blood cortisol levels of brown trout under intensive culture conditions. In: Lofts, B. and Holms, W.N. (Edn.), Current Trends in Endocrinology. Hong Kong University, pp. 1239-1242.

24. Ando M, Toyohara H, Sakaguchi M (1992) Post mortem tenderization of rainbow trout muscle caused by the disintegration of collagen fibres in the pericellular connective tissue. Nippon Suisan Gakkaishi 58(1992): 567-570.

25. Robb DHF, Kestin SC, Warriss PD (2000) Muscle activity at slaughter: I. Changes in flesh colour and gaping in rainbow trout. Aquaculture 182(3-4): 261269.

26. Nakayama T, Toyoda T, Ooi A (1994) Physical property of carp muscle during rigor tension generation. Fisheries Science 60: 717-721.

27. Lowe TE, Ryder JM, Carragher JF, Wells RMG (1993) Flesh quality in snapper, Pagrus auratus, affected by capture stress. Journal of Food Science 58(4): 770773.

28. Skjervoldt PO, Fjaera SO, Ostby PB (1999). Rigor in Atlantic salmon as affected by crowding stress prior to chilling before slaughter. Aquaculture 175(1-2): 93-101.

29. Bagni M, Civitareale C, Priori A, Ballerini A, Finoia M, et al. (2007) Pre-slaughter crowding stress and killing procedure affecting quality and welfare in sea bass (Dicentrarchus labrax) and sea bream (Sparus aurata). Aquaculture 263: 53-60. 


\section{International Journal of Oceanography \& Aquaculture}

30. Robb DHF, Frost S (1999) Welfare and quality. What is the relationship? Presentation at Innovation for seafood'99, Surfer's Paradise, Queensland, Australia 21-23 April.

31. Erikson U, Misimi E (2008) Atlantic salmon skin and fillet colour changes effected by perimortem handling stress, rigor mortis, and ice storage. J Food Sci 73(2): 50-59.

32. Borderias AJ, Sanchez-Alonso I (2011) First processing steps and the quality of wild and farmed fish. J Food Sci 76(1): 1-5.

33. Halliwell B, Gutteridge JMC (1984) Oxygen toxicity, oxygen radicals, transition metals and disease. Biochem J 219(1): 1-14.

34. Nakayama T, Kaneko M, Kodama M (1986) Detection of DNA damage in cultured human fibroblasts induced by methyl linoleate hydroperoxide. Agricultural and Biological Chemistry 50(1): 261-262.

35. Tabner BJ, Turnbull S, Al-Agnaf O, Allsop D (2001) Production of reactive oxygen species from aggregating proteins implicated in Alzheimer's disease, Parkinson's disease and other neurodegenerative diseases. Curr Top Med Chem 1(6): 507-517.

36. Sevanian A, Peterson H (1986) Induction of cytotoxicity caused by terbutylhydroperoxide: free radical scavenging versus iron chelating mechanism. Free Radical Biology \& Medicine 25: 196-200.

37. Robb DHF (2001) The relationship between killing methods and quality. In: Kestin, S. C. and Warriss, P.D. (eds.), Farmed Fish Quality. Fishing News Books, Oxford, pp. 220-233.

38. Rostagno MH (2009) Can stress in farm animal's increases food safety risk. Foodborne Pathog Dis 6(7): 767-776.
39. Erikson U (1997) Muscle quality of Atlantic salmon (Salmo salar) as affected by handling stress. Doctoral Thesis. Norwegian University of Science and Technology, Trondheim, Norway, pp. 68.

40. Robb DHF, Kestin SC (2002) Methods used to kill fish: field observations and literature reviewed. Animal Welfare 11(3): 269-282.

41. Brethe FCJ (2011) Risk assessment of animal WelfareRecent examples. TAIEX Workshop on animal health and regional policies to support trade.

42. Mochizuki S, Sato A (1994) Effects of various killing procedures and storage temperatures on postmortem changes in the muscle of horse mackerel. Nippon Suisan Gakkaishi 60(1): 125-130.

43. Kestin SC, Wotton SB, Adams S (1995) The effect of $\mathrm{CO}_{2}$, concussion or electrical stunning of rainbow trout (Oncorhynchus mykis) of fish welfare. In: Quality in Aquaculture. Special Publication 23. European Aquacultural Society, pp. 380-381.

44. Warriss PD, Wotton SB (1981) Effect of cardiac arrest on exsanguination in pigs. Res Vet Sci 31(1): 82-86.

45. Warriss PD, Wilkins LJ (1986) Exsanguination of meat animals. Proceedings of CEC Seminar, June, Brussels, pp 150-158.

46. Aske Land Midling K (2001) Slaughtering of Atlantic halibut (Hippoglossus hippoglossus): effects on quality and storing capacity. In: Kestin S C and Warriss P D (eds) Farmed Fish Quality p 38. Blackwells: Oxford, UK.

47. Morzel M, Sohier D, Van de Vis H (2003) Evaluation of slaughtering methods for turbot with respect to animal welfare and flesh quality. Journal of the Science of Food and Agriculture 83(1): 19-28. 